Katarzyna Dojwa-Turczyńska

Uniwersytet Wrocławski

DOI: 10.19195/2450-274X.2.5

\title{
Stosunek Polaków do migrantów. Refleksje socjologiczne w świetle wybranych badań empirycznych
}

Abstrakt: Kryzys migracyjny roku 2015 można rozpatrywać z różnych perspektyw. Jedną $\mathrm{z}$ nich jest płaszczyzna społeczna, która $\mathrm{w}$ niniejszym artykule odnosi się do stosunku mieszkańców danego państwa do kwestii uchodźców. Tym społeczeństwem są Polacy. Generalnie stosunek Polaków do innych wedle badań porównawczych w latach 2002-2012 był korzystny. Wśród Europejczyków Polacy sytuowali się na stosunkowo wysokich pozycjach tolerancji dla tych, którzy w Polsce będą szukać schronienia bądź też zdecydują się tu żyć. Badania sondażowe pokazywały także relatywnie bardziej przychylne dla innych postawy Polaków względem społeczeństw Grupy Wyszehradzkiej. Badania ilościowe realizowane w 2015 r. pokazują, że w stosunku do innych społeczeństw Polacy nadal reprezentują postawy stosunkowo przychylne migrantom. Niemniej jeśli analizuje się w tym zakresie zmiany postaw w stosunku do poprzedniego badania, widoczne staje się coraz większe zamknięcie Polaków na obcych i niechęć do ich przyjmowania.

Słowa kluczowe: migracje, uchodźcy, opinia publiczna, badania sondażowe, badania jakościowe, postawy społeczne

The attitude of Polish citizens toward migrants. Socjological reflections in the light of chosen empirical research.

Abstract: The 2015 migration crisis can be viewed from various perspectives. One of them is the social level, which in this paper refers to the attitude of a country's inhabitants to the issue of refugees. Here, Poles comprise such a society. Generally, Poles' attitude to others, according to comparative studies in the period 2002-2012, was positive. Among Europeans, Poles occupied relatively high positions in terms of tolerance towards those that would seek refuge or decide to live in their country. Sample surveys also showed relatively more sympathetic attitudes of Poles to others compared to other societies within the Visegrad Group. Quantitative studies conducted in 2015 show that compared to other societies, Poles still present relatively sympathetic attitudes to 
incomers. However, if we analyse changes of attitudes compared to the previous survey, we can see that Poles are increasing closed to foreigners and unwilling to accept them. attitude

Keywords: migrations, refugees, public opinion, polls studies, qualitative studies, social

\section{Wstęp}

Nawet pobieżna analiza tytułów prasowych i zawartości programów informacyjnych prowadzi nas do wniosku, że w roku 2015 jednym z najistotniejszych „newsów” był tzw. kryzys migracyjny. Był on omawiany w bardzo różnych kontekstach. W wymiarze politycznym pojawiał się zarówno w odniesieniu do aktywności Unii Europejskiej, jak i rozmaitych organizacji międzynarodowych, deklaracji i działań poszczególnych państw, zapowiedzi i prognoz polityków. W odsłonie gospodarczej wskazywano m.in. na potencjał kadrowy, ale także zwiększanie wydatków budżetowych poszczególnych państw wpływające na ożywienie koniunktury. W ujęciu społecznym istotny był przede wszystkim aspekt demograficzny, podkreślano niski przyrost naturalny Europejczyków i generalne starzenie się europejskiej populacji, ale także zaznaczano pozytywne aspekty wielokulturowości. Wreszcie z perspektywy aksjologicznej wskazywano na aspekty humanitarne, podnosząc imperatyw pomocy tym, którzy uciekają przed wojną, śmiercią i głodem z innych części globu. Oczywiście powyższe przykłady nie wyczerpują kontekstów w których problematyka migracji i migrantów się pojawiała. Dodatkowo wraz z intensyfikacją napływu do Unii Europejskiej obywateli innych państw pojawiały się także inne aspekty, które z pewnością zostaną niebawem opisane. Faktem pozostaje, że kryzys migracyjny zaabsorbował uwagę rozmaitych instytucji i organizacji, jak i społeczeństw - w tym także społeczeństwa polskiego. I właśnie stosunkowi Polaków do kwestii migrantów poświęcono niniejszy artykuł. Próbę odpowiedzi na pytanie o to, jaki jest stosunek Polaków do migrantów, nakreślono głównie na podstawie sondaży opinii CBOS, niemniej — ponieważ kwestia stosunku do migrantów pojawiała się już wcześniej w badaniach Europejskiego Sondażu Społecznego - także te wyniki pokrótce przytoczono. Zwrócono uwagę także na to, jakie możliwości eksploracyjne niesie za sobą wykorzystanie badań jakościowych.

\section{Migrare humanum est}

Wydaje się, że rok 2015 z perspektywy Unii Europejskiej, a także Europejczyków przejdzie do annałów kojarzony głównie z kryzysem migracyjnym. Problematyka migracji w dziejach ludzkości nie jest zagadnieniem nowym, w różnych okresach, w rozmaitych częściach globu, z ekonomicznych, politycznych czy nawet kulturowych przyczyn dochodziło do przemieszczania się ludzi. Prześladowania i groźba eksterminacji na podłożu politycznym czy religijnym czyniła niektóre 
miejsca na globie niebezpiecznymi dla wybranych grup, a możliwość znalezienia pracy, „chleba” i godnego życia wypychała rdzennych mieszkańców społeczeństw rolniczych do państw rewolucji przemysłowej. „Migracje są odwieczną cechą dziejów ludzkości, jej rozprzestrzeniania się po całym niemal obszarze globu ziemskiego"'. Twierdzenie, iż migrare humanum est (przemieszczanie się jest rzeczą ludzką) nabrało szczególnego wymiaru współcześnie, kiedy to w świecie globalnej wioski techniczne środki komunikacji skróciły czas podróży pomiędzy jednym miejscem a drugim, zaś nowe technologie sprawiły, że popularyzacji uległy pewne atrybuty kultury Zachodu.

Na przełomie XIX i XX w. pojawiło się pojęcie „europeizacji świata”, odnoszące się do poszukiwania przez Europejczyków nowego miejsca do zamieszkania i życia. W latach 1830-1930 60 mln osób opuszcza Stary Kontynent, większość (40 mln) na niego nie wraca. Dwie trzecie kieruje się do Stanów Zjednoczonych, determinowane szansą jaką stwarza w USA rewolucja przemysłowa. „Z europejskich krajów rozwiniętych do pustych przestrzeni nowych kontynentów ruszali najbardziej dynamiczni i energiczni, przeważnie jednak niewykwalifikowani, kierując się początkowo do pracy w rolnictwie, potem w przemyśle"2.

Jeśli chodzi o Polaków, to najwięcej emigrantów pochodziło z Galicji. W 1882 r. w Galicji na jedno gospodarstwo rolne przypadało 5 mórg ziemi, natomiast aby utrzymać sześcioosobową rodzinę, trzeba było uprawiać minimum 10 mórg... „Roczne umierało tam z głodu 50 tys. osób. Ponadto część poborowych ze wszystkich zaborów pragnęła uniknąć uciążliwej służby wojskowej”3. W przypadku niższych warstw ludności na plan pierwszy wysuwały się motywy ekonomiczne, aczkolwiek trudno jest pominąć także aspekt polityczny — imperatyw służby wojskowej w armii państwa zaborczego. Na emigrację decydowali się również przedstawiciele warstw wyższych, czego dobitnym przykładem jest postać wybitnego polskiego socjologa, Floriana Znanieckiego ${ }^{4}$.

Początkowo Ameryka była stosunkowo otwarta na obcych, wraz z ich napływem procedury „poboru” ulegały instytucjonalizacji, jednak pojawiły się z czasem rozmaite ograniczenia. Statki z emigrantami przybijały do Castle Garden, potem (od 1890) na Ellis Island, gdzie emigranci czekali na wpuszczenie na teren USA. Przeprowadzano badania lekarskie, dokonywano kontroli celnej, spisywano imię i nazwisko oraz narodowość przybysza, pytano o adresy osób, które imigrantów zaprosiły oraz o posiadaną przez emigranta sumę pieniędzy. „Władzom amery-

${ }^{1}$ J.E. Zamojski, Migracje masowe - czynnik przemian współczesnych społeczeństw, [w:] Migracje i społeczeństwo. Zbiór studiów, red. J.E. Zamojski, Warszawa 1995, s. 9.

${ }_{2}^{2}$ M. Nalewajko, Migracje: ewolucja zjawiska, [w:] Migracje i społeczeństwo. Zbiór studiów, Warszawa 1995, s. 45-46.

${ }^{3}$ B. Biedaka, Osadnictwo polonijne w ośrodkach miejskich na północno-wschodnim wybrzeżu Stanów Zjednoczonych Ameryki Północnej (1870-1914), [w:] Migracje i społeczeństwo..., s. 83.

${ }^{4}$ Por. m.in. E. Hałas, Znaczenia i wartości społeczne. O socjologii Floriana Znanieckiego, Lublin 1991, s. 9-10 oraz Z. Dulczewski, Sprawa polska w biografii i twórczości Floriana Znanieckiego, [w:] Socjologia polityczna Floriana Znanieckiego a wspótczesna polityka, red. O. Sochacki, Gdańsk 1996. 
kańskim obojętny był los imigrantów, ponadto pod wpływem związków zawodowych zaostrzono przepisy imigracyjne w 1888, 1891 i 1893 roku. Wprowadzono zakaz osiedlania się osób skazanych za przestępstwa z tzw. niskich pobudek, cho-

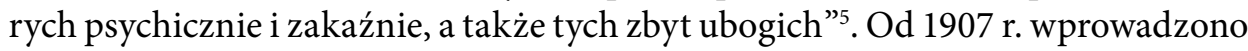
podatek imigracyjny, zaś osoby poniżej 16 roku życia nie mogły wjechać na teren USA bez rodziców ${ }^{6}$. Rozległy terytorialnie kraj rewolucji przemysłowej potrzebował rąk do pracy, ale twarde zasady kapitalizmu bez ludzkiej twarzy eliminowały poza nawias społeczeństwa nie tylko tych, którzy owej pracy podejmować nie chcieli, ale także tych, którym się nie udało. Dobrym przykładem pokazującym losy imigrantów stała się książka Uptona Sinclaira - Dżungla ${ }^{7}$, która nota bene zamiast wstrząsnąć społeczeństwem w kontekście humanitarnym, doprowadziła do zmian w sposobie produkcji mięsa ${ }^{8}$.

Poza okresem zaborów, także w późniejszych epokach w historii społeczeństwa polskiego zdarzały się sytuacje, które prowadziły do migracji Polaków. Istotnym okresem współczesnej historii są tu przemieszczenia ludności związane z II wojną światową i „powrotem” repatriantów z tych ziem kraju, które w nowych granicach państwa już się nie znalazły. Zmiana systemu doprowadziła także do tego, że część rodaków, znalazłszy się poza późniejszym obszarem PRL, chciała lub musiała pozostać na terenie innego państwa. W latach późniejszych istotną kwestią były represje władz PRL wobec działaczy antysystemowej opozycji, ale także chęć polepszenia warunków życia i emigracja do rozwiniętych krajów Zachodu. III RP nie może się także poszczycić pozytywnym saldem migracji. Wejście Polski do UE uruchamia kolejną falę wyjazdów z kraju, przy czym wydaje się, że najsilniejszym czynnikiem wypychającym jest otwarcie rynków pracy połączone z sytuacją polskiego rynku pracy.

O ile w przypadku społeczeństwa polskiego okresu dwudziestolecia międzywojennego moglibyśmy mówić o pewnym zróżnicowaniu etnicznym i kulturowym, o tyle inaczej jest już w okresie PRL. Ta względna jednolitość będzie widoczna dekadę i dwie po rozpoczęciu transformacji systemowej. Wprawdzie w Polsce pojawią się przedstawiciele innych nacji, kultur, mieszkańcy pozaeuropejskich kontynentów, niemniej ich udział w całości populacji będzie praktycznie śladowy.

\section{Ustalenia terminologiczne}

Przemieszczanie się jednostek w znaczeniu horyzontalnym sytuuje się w obszarze zainteresowań wielu nauk. Ruch przestrzenny ludności czy też ruch

${ }^{5}$ B. Biedaka, op. cit., s. 85 .

${ }^{6}$ Ibidem, s. 86.

${ }^{7}$ W polskich edycjach dominował tytuł Grzęzawisko (Por. Upton Sinclair, Grzęzawisko, przeł. A. Niemojewski, Warszawa 1907).

${ }^{8}$ K. Frysztacki, Socjologia problemów społecznych, Warszawa 2010, s. 222-223. 
wędrówkowy określa się mianem migracji. Pojęcie to ma nie tylko neutralny poznawczo charakter, dodatkowo jest ono nadrzędne w stosunku do używanych w artykule terminów „emigracja” oraz „uchodźstwo”.

Definicyjnie migracja jest to ruch ludności, „przemieszczanie się jednostek i grup ludzkich z jednego terytorium na inne”. Migracje to zmiana miejsca pobytu mająca charakter stały lub czasowy. Biorąc pod uwagę czynnik sprawczy, migracje dzieli się na indywidualne i grupowe, międzynarodowe i wewnętrzne, ekonomiczne, społeczne, polityczne oraz religijne, a także dobrowolne i przymusowe. Jeśli chodzi o formę, to najczęściej wskazuje się na emigrację, imigrację oraz reemigrację i repatriację. Z punktu widzenia niniejszej problematyki to właśnie termin emigracja nabiera znaczenia kluczowego. Jest to ruch wędrówkowy ludności związany ze zmianą miejsce zamieszkania ${ }^{10}$, „opuszczanie kraju ojczystego w celu stałego lub czasowego zamieszkiwania w innym państwie"11. Zbiorowość ludzi objętych tym ruchem określa się mianem emigrantów. W badaniu ruchów wędrówkowych ludności uwzględnia się obszar, na którym przemieszcza się ludność, czas pobytu w nowym miejscu (lub czas nieobecności w poprzednim), cel zmiany miejsca zamieszkania. Biorąc pod uwagę ostatni z elementów, emigrację można klasyfikować jako ekonomiczną (zarobkową), polityczną, religijną, przymusową, dobrowolną ${ }^{12}$. Imigracja to analogicznie ruch wędrówkowy ludności uwzględniony ze strony kraju przybycia ${ }^{13}$.

Uchodźca - zgodnie z konwencją genewską z dnia 28 lipca 1951 r. - to osoba, która „na skutek uzasadnionej obawy przed prześladowaniem z powodu swojej rasy, religii, narodowości, przynależności do określonej grupy społecznej lub z powodu przekonań politycznych przebywa poza granicami państwa, którego jest obywatelem, i nie może lub nie chce z powodu tych obaw korzystać z ochrony tego państwa, albo która nie ma żadnego obywatelstwa i znajduje się, na skutek podobnych zdarzeń, poza państwem swojego dawnego, stałego zamieszkania i nie może lub nie chce z powodu tych obaw powrócić do tego państwa" ${ }^{14}$.

Powyższe ustalenia definicyjne będą istotne w dalszej części artykułu. Prezentowane badania empiryczne będą posługiwać się rozmaitą stylistyką — niekiedy respondentów będzie się pytać o uchodźców w sposób bezpośredni, kiedy indziej termin „uchodźca” nie pojawi się, choć treść pytania odnosić będzie się właśnie to tej kategorii osób. Stąd też interpretując ich wyniki w dalszej części artykułu, starano się zachować nomenklaturę słowną stosowaną przez autorów poszczególnych badań. Pojawi się jeszcze jedna kwestia. Kanony metodologii nauk spo-

${ }^{9}$ K. Olechnicki, P. Załęcki, Słownik socjologiczny, Toruń 1997, s. 129.

${ }^{10}$ Leksykon polityki społecznej, red. B. Rysz-Kowalczyk, Kraków 2001, s. 48.

${ }^{11}$ K. Olechnicki, op. cit., s. 56.

12 B. Rysz-Kowalczyk, op. cit., s. 48.

13 Ibidem, s. 60.

${ }^{14}$ A. Florczak, Uchodźcy, [w:] Encyklopedia politologii, red. M. Żmigrodzki, t. 5: Stosunki międzynarodowe, red. T. Łoś-Nowak, Kraków 2002, s. 377. 
łecznych nakładają na badaczy imperatyw stosowania w narzędziach badawczych terminów o charakterze neutralnym, unikania obciążonych pytań i pojęćc ${ }^{15}$. Jednak wraz z falą osób przybywających do Europy w 2015 r. terminy neutralne badawczo, takie jak wskazany powyżej „uchodźca”, ale także „emigrant”, nabiorą emocjonalnej warstwy znaczeniowej...

\section{Stosunek Polaków do „obcych" na tle opinii Europejczyków}

Proces akcesji Polski do Unii Europejskiej miał wymiar nie tylko polityczny i gospodarczy, ale także społeczny. Jeszcze w okresie przedakcesyjnym realizowane były badania sytuujące Polaków wśród innych nacji Europy. Badaczy interesowały warunki życia w Polsce, religijność społeczeństwa, efektywność i zaufanie dla insty tucji, aktywność obywatelska i polityczna Polaków. Jednym z badań ukazujących Polaków na tle innych europejskich nacji będzie Europejski Sondaż Społeczny. Badanie było realizowane cyklicznie co dwa lata w różnych krajach Unii, począwszy od $2002 \mathrm{r}$. W jego poszczególnych edycjach uczestniczyło od 22 do 30 państw Unii Europejskiej i krajów spoza wspólnoty ${ }^{16}$. Polska brała udział w każdej edycji, co z punktu widzenia konstrukcji czasowych analiz porównawczych jest bardzo istotne, gdyż pozwala śledzić pewne trendy.

W tym miejscu opisane zostaną wyniki badania z 2012 r. dotyczące stosunku Polaków do innych nacji i kultur, potencjalnych migrantów zainteresowanych przybyciem i osiedleniem się w Polsce.

W 2012 r. Europejczycy pozytywnie odnosili się do przyjmowania i osiedlania się migrantów podobnych etnicznie w swoich krajach. Blisko siedmiu na dziesięciu badanych (68\%) było zdania, że ich kraj powinien pozwalać na przyjazd i osiedlenie się dużej lub pewnej liczbie obcych, zaledwie $1 / 3$ (32\%) była zdania, że owe przyjazdy należałoby ograniczyć lub wyeliminować (odpowiedź „nie zezwalać nikomu" wybrało zaledwie 9\% badanych Europejczyków). Badanie pokazało, że generalnie Polacy są nacją dość otwartą na imigrację osób podobnych pod względem etnicznym. Wedle siedmiu na dziesięć badanych (dokładnie 77\%) Polska powinna być otwarta na osoby, które będą chciały w niej zamieszkać. Zaledwie nieliczni (4\%) wskazywali, że Polska nie powinna zezwalać nikomu na przyjazd i zamieszkanie, nieco więcej badanych (19\%) opowiadało się za otwartością relatywną i wyrażaniem zgody na przyjazd i pobyt tylko wybranym emigrantom. Stosunek Polaków do „obcych” w tym badaniu był nader otwarty — jedynymi nacjami, które w wyższym stopniu deklarowały taką otwartość byli tylko: Island-

${ }^{15}$ E. Babbie, Badania społeczne w praktyce, Warszawa 2004, s. 275.

${ }^{16}$ Więcej na temat badania P.B. Sztabiński, Dlaczego Europejski Sondaż Społeczny, [w:] PolskaEuropa. Wyniki Europejskiego Sondażu Społecznego 2002-2012, red. P.B. Sztabiński, F. Sztabiński, Warszawa 2014, s. 6-7. 
czycy (93\%), Niemcy i Szwedzi (89\%) oraz Duńczycy $(82 \%)^{17}$. Pozytywne opinie na temat imigrantów sygnalizowało zdecydowanie mniej mieszkańców Cypru (34\%), Portugalii (41\%), Czech (44\%) i Węgier (48\%)

Powyższe wskazania odnosiły się do osób z innych nacji, niemniej podobnych etnicznie. W przypadku przedstawicieli innej rasy, albo też innej grupy etnicznej, ta otwartość społeczeństw europejskich była już niższa. Ogółem ponad połowa (52\%) uczestników badania deklarowała pełną lub selektywną otwartość na inne kultury i rasy, porównywalny odsetek był jednak przeciwnego zdania. Tym razem odsetek osób opowiadających się przeciwko przyjmowaniu kogokolwiek wzrósł do $16 \%$ badanych $^{18}$. Opinie Polaków trudno uznać za zbliżone do opinii Europejczyków in gremio: $23 \%$ opowiada się za nieograniczonym przyjęciem, kolejne $46 \%$ to zwolennicy poglądu, aby na przyjazd i pobyt zezwalać określonej liczbie migrantów (suma to 69\%). Osoby chłodno i negatywnie odnoszące się do migrantów to zaledwie $31 \%$, w tym osób opowiadającym się przeciw „obcym” jest zaledwie $7 \%$. Wskazania Polaków sytuują ich ponownie wśród nacji najbardziej otwartych nie tylko na migrantów podobnych etnicznie, ale tym razem - etnicznie i religijnie odmiennych. Krajami bardziej tolerancyjnymi dla innych etnicznie i rasowo są tu: Szwecja (87\%), Islandia (74\%), Niemcy (72\%), Norwegia (71\%). Natomiast wśród krajów, w których odsetki osób gotowych na przyjęcie osób etnicznie i rasowo odmiennych są najniższe, królują: Cypr (12\%), Węgry (25\%), Czechy (32\%), Izrael (31\%), Portugalia (36\%), Rosja (37\%).

Jeszcze mniej korzystny był stosunek Europejczyków do osób, które chcą przybyć do Europy z biedniejszych państw pozaeuropejskich. Tym razem osoby opowiadające się za otwartością stanowią mniejszą część populacji badanej (44\% uczestników badania), dominują natomiast ci (56\%), którzy są za przyjmowaniem nielicznych lub też rezygnacją z otwartości (w tej puli $21 \%$ stanowią właśnie przeciwnicy przyjmowania migrantów). Ponownie Polacy sytuują się wśród nacji otwartych na migrantów. Za ich przyjmowaniem opowiada się $69 \%$ badanych, sceptycznie nastawionych jest 31\% respondentów (zaledwie 7\% uważa, że nikomu nie powinno się pozwolić na przyjazd i pobyt). Podobnie jak to było w przypadku wcześniejszych pytań, bardziej otwarci na emigrantów zarobkowych są Szwedzi (84\%), Islandczycy (74\%), Niemcy (70\%), mniej otwarci zaś mieszkańcy Cypru (8\%), Węgrzy (19\%), mieszkańcy Izraela (22\%), Rosjanie (31\%), Portugalczycy i Estończycy (32\%) oraz Czesi $(33 \%)^{19}$.

Badania pokazują, że zarówno jeśli chodzi o otwartość na osoby podobne etnicznie, jak i te, które różnią się pochodzeniem i kolorem skóry, czy wreszcie na tych, którzy mogą przybyć spoza Europy z biedniejszych państw świata, to większość Polaków jest takim migracjom przychylna. I trudno jest to łączyć tylko i wyłącznie z wynikami badania AD 2012. Poniżej zaprezentowano tabelę ilustrującą odsetki

${ }^{17}$ K. Wysieńska, Opinia publiczna wobec kwestii napływu cudzoziemców, [w:] Polska-Europa...

18 Ibidem, s. 53.

19 Ibidem, s. 54. 
respondentów z Polski deklarujących, że Polska powinna przyjąć wszystkich tych migrantów, którzy wyrażą wolę przybycia i zamieszkania w kraju (tabela 1).

Tabela 1. Odsetek respondentów deklarujących otwartość wobec skrajnie liberalnej polityki migracyjnej w poszczególnych rundach Europejskiego Sondażu Społecznego w Polsce

\begin{tabular}{|l|c|c|c|c|c|c|}
\cline { 2 - 7 } \multicolumn{1}{c|}{} & 2002 & 2004 & 2006 & 2008 & 2010 & 2012 \\
\hline Zgoda na liczną migrację osób podobnych etnicznie & 13 & 22 & 30 & 29 & 30 & 29 \\
\hline Zgoda na liczną migrację osób innych etnicznie & 9 & 16 & 24 & 24 & 22 & 23 \\
\hline $\begin{array}{l}\text { Zgoda na liczną imigrację osób z biedniejszych krajów } \\
\text { spoza Europy }\end{array}$ & 9 & 16 & 24 & 24 & 21 & 24 \\
\hline
\end{tabular}

Źródło: K. Wysieńska, Opinia publiczna wobec kwestii naplywu cudzoziemców, [w:] Polska-Europa. Wyniki Europejskiego Sondażu Społecznego 2002-2012, red. Paweł B. Sztabiński, F. Sztabiński, Warszawa 2014, s. 59.

Przypomnijmy, że zaprezentowane w ujęciu tabelarycznym opinie mają charakter skrajny, niemniej analiza zaprezentowanych powyżej wyników sześciu kolejnych rund badania sprowadza się do praktycznie jednej konkluzji: od czasu wejścia Polski do UE opinie Polaków w tej kwestii zdawały się być ustabilizowane. Trywializując, możemy wskazać, że w 2012 r. niemal 1/4 respondentów opowiadała się za bezlimitowym przyjęciem do Polski wszystkich tych z biedniejszych krajów pozaeuropejskich, którzy wyrażą wolę przyjazdu. Jeśli do owych wskazań dodalibyśmy także wskazania respondentów, którzy uznali, że możliwe byłoby przyjęcie pewnej liczby osób zainteresowanych pobytem w Polsce, to Polacy prezentowaliby się wśród Europejczyków jako społeczeństwo ponadprzeciętnie otwarte na innych. Nie dziwią zatem słowa, iż na poziomie przynajmniej deklaratywnym, społeczeństwo polskie „,echuje się wyjątkowo korzystną oceną konsekwencji imigracji i otwartością na imigrantów”20.

Dotychczasowe sześć edycji badania pokazywało pozytywny stosunek Polaków do szeroko rozumianych ,innych”, którzy chcieliby przybyć do kraju i w nim zamieszkać. Na przełomie kwietnia i września 2015 r. na terenie Polski zrealizowano badania sondażowe edycji siódmeje ${ }^{21}$. Ich wyniki będą na początku $2016 \mathrm{r}$. prezentowane $w$ innych miejscach, dlatego też ograniczmy się tu do prezentacji jednego wymiaru - stosunku Polaków do imigrantów z biedniejszych państw pozaeuropejskich. Jeśli chodzi o przyjmowanie imigrantów ekonomicznych, to podobnie jak miało to miejsce w 2012 r., tak i 2015 r. Polska znalazła się wśród krajów relatywnie otwartych ${ }^{22}: 12,8 \%$ respondentów wskazywało, że Polska powinna

${ }^{20}$ Ibidem, s. 59.

${ }^{21}$ Co istotne, w większości krajów Europy badania realizowano na przełomie roku 2014-2015. Por. K. Andrejuk, Postawy wobec imigrantów świetle wyników Europejskiego Sondażu Społecznego 2014-2015. Polska na tle Europy, „European Studies Unit” 2015/2, Warszawa, grudzień 2015, s. 4.

${ }^{22}$ Wprawdzie w badaniu ESS brały udział 22 kraje, niemniej ze względu na brak dostępności danych z niektórych państw prezentowane jest tu zestawienie odnoszące się do 14 państw. Niedobór generuje brak możliwości prezentacji uśrednionych wskazań dla Europejczyków. 
przyjąć wielu imigrantów ekonomicznych z biednych krajów pozaeuropejskich, zaś 39,6\% - że przyjąć ich pewną liczbę. Przypomnijmy, że te typy wskazań kumulowano, omawiając badanie edycji szóstej, zakładając, że są to postawy pozytywne względem innych. Podążając tym tropem, oznaczałoby, że w roku 2015 r. ponad połowa $(52,4 \%)$ zapytanych wyrażałaby pozytywny stosunek do imigrantów ekonomicznych. W stosunku do badania z roku 2012 r. widoczny byłby wyraźny spadek opinii przychylnych obcokrajowcom $z$ biednych państw pozaeuropejskich. Negatywnie do tej kwestii odnosiłoby się 47,7\% badanych (przy czym $13,2 \% \mathrm{w}$ formie kategorycznej). Polska nie zajmuje w roku $2015 \mathrm{r}$. tak wysokiej pozycji w rankingu otwartości na cudzoziemców, jak w roku 2012 r. Bardziej tolerancyjne są: Szwecja (87,4\%), Norwegia (68\%), Niemcy (64,1\%), Szwajcaria (55,6\%), Holandia (53,5\%), Belgia $(52,4 \%)^{23}$. Nadal jednak trudno jest orzekać o zamknięciu Polaków na obcych...

\section{Respondenci z Polski o uchodźcach na tle społeczeństw Grupy Wyszehradzkiej}

Wśród badań porównawczych dotyczących stosunku do migrantów na uwagę zasługują również badania sondażowe $\mathrm{z}$ udziałem respondentów $\mathrm{z}$ Polski, a także Czech i Słowacji oraz Węgier. We wstępie z badania z 2005 r. czytamy, iż: „W porównaniu z pozostałymi społeczeństwami państw Grupy Wyszehradzkiej Polacy są najbardziej otwarci na przybyszów z innych krajów"24. Wprawdzie wtedy respondenci z Europy Środkowej generalnie uznawali, że cudzoziemcy w ich kraju są niepotrzebni (na Węgrzech i na Słowacji takie wskazania stanowiły 80 i 79\%, a w Polsce i w Czechach 71 i 70\%), jednak wtedy za bezwarunkowym prawem każdego człowieka, który wyrazi chęć przyjechania i zamieszkania w danym kraju, opowiadało się aż 62\% Polaków i zaledwie 30\% Słowaków, 26\% Czechów oraz 23\% Węgrów. W konkluzji końcowej raportu wskazywano natomiast, że „Czesi, Węgrzy i Słowacy wyraźnie rzadziej niż Polacy opowiadają się za tym, żeby przyjmować wszystkich uchodźców politycznych, rzadziej też sądzą, że nikomu nie należy udzielać azylu"25.

Dekadę później zrealizowane zostało badanie, które ponownie pokazało pewną specyfikę Polski na tle Czech i Słowacji oraz Węgier. Na przełomie września i października 2015 r. wszyscy respondenci byli stosunkowo otwarci na możliwość przyjęcia uchodźców z krajów objętych konfliktami zbrojnymi. Takie deklaracje

${ }^{23}$ W kontekście dalszej części artykułu warto wskazać, że badania w tych wszystkich państwach realizowane były zdecydowanie wcześniej niż w Polsce, najczęściej na przełomie lat 2014/2015.

${ }^{24}$ Opinie ludności krajów Europy Środkowej o imigrantach i uchodźcach, BS 2005, nr 60, CBOS, Warszawa, marzec 2005.

${ }^{25}$ Ibidem. 
najczęściej składali Węgrzy (65\% wskazań), następnie Polacy (56\%), dopiero w dalszej kolejności Czesi (zaledwie 44\% wskazań) i Słowacy (tu zaledwie 33\% wskazań akceptujących warunkowe lub bezwarunkowe przyjęcie uchodźców). Analogicznie przeciwników przyjęcia jakichkolwiek uchodźców do kraju było zatem najwięcej na Słowacji (62\%), w Czechach (50\%), w Polsce (40\%) i na Węgrzech $(32 \%)^{26}$. Literalne odczytanie wyniku zaskakuje, ponieważ Węgry to kraj, w którym rozmaite badania prezentowały dość chłodny stosunek do innych. Powyższe pytanie dotyczyło uchodźców z krajów objętych konfliktami zbrojnymi, przypomnijmy - tych ludzi, którzy przez wzgląd na swoje zdrowie i życie nie mogą przebywać na terenie swojego państwa. Nie dysponujemy wynikami badań z różnych krajów, które pozwoliłyby nam zdekodować, kim dla przedstawicieli poszczególnych społeczeństw jest ów „uchodźca”, oraz czy w komunikacji politycznej i w przekazach medialnych wprowadza się wyraźne rozróżnienie pomiędzy nim a emigrantem. Stąd też być może mamy do czynienia z sytuacją, w której uchodźcy dla węgierskich respondentów to biedni ludzie uciekający przez wojennym kataklizmem, szukający schronienia, tacy, którym - wedle większości respondentów - należy pomóc. Tłumy młodych mężczyzn szturmujących granicę państwową, czy dewastujących dworzec kolejowy w Budapeszcie, niesione obietnicami dostatniego życia w Niemczech, Austrii czy Skandynawii do tej kategorii już nie należą.

Analizując wskazania respondentów dotyczące kolejnego pytania, nie natrafiamy już na tego typu trudności interpretacyjne. Kolejne zagadnienie dotyczyło tego, czy uchodźcy z Bliskiego Wschodu oraz Afryki, których zagospodarować nie mogą już inne kraje UE, powinni być przyjmowani do Polski, Czech, Słowacji i Węgier. Zwolennikami przyjęcia takich uchodźców jest 47\% Polaków, 26\% Czechów, 23\% Słowaków oraz 21\% Węgrów. Ta otwartość będzie jednak wyższa, kiedy respondenci zostaną zapytani o potencjalną możliwość przyjmowania uchodźców z terenu Ukrainy. Otwartość wyrazi tu $61 \%$ badanych Polaków, 44\% Słowaków i 43\% Czechów. Pomijając wciąż żywe konotacje historyczne dotyczące zbrodni $\mathrm{UPA}^{27}$, zwraca uwagę stosunkowo wyższa akceptacja dla udzielania schronienia „obcym”, którzy pod względem etnicznym czy kulturowym nie są tak odmienni, jak ci z Afryki i Bliskiego Wschodu.

Jeśli chodzi o obawy co do obecności uchodźców w danym kraju, to ogólnie Polacy są mniej krytyczni względem obcych od innych nacji Wyszehradu ${ }^{28}$. W każdym z wymiarów opinie Polaków są w widoczny sposób mniej nieprzychylne względem obcych w stosunku do wskazań Węgrów, Słowaków oraz Czechów.

${ }^{26}$ Stosunek do uchodźców w krajach Grupy Wyszehradzkiej, 2015, nr 151, CBOS, Warszawa, listopad 2015.

${ }^{27}$ Więcej na ten temat: M. Dębicki, J. Makaro, Polacy wobec Ukrainy i Ukraińców w latach 2012-2014 - refleksje na marginesie badań sondażowych, [w:] Sąsiedztwa III RP - Ukraina. Zagadnienia społeczne, red. M. Dębicki, J. Makaro, Wrocław 2015, s. 7-30.

${ }^{28}$ Stosunek do imigrantów w krajach Grupy Wyszehradzkiej, 2015, nr 178, CBOS, Warszawa, grudzień 2015. 
Generalnie w każdym z wymiarów wskazania Polaków są korzystniejsze dla cudzoziemców - dominują tu nie tylko wskazania mniej krytyczne, ale niekiedy największą liczbę wskazań zyskują sądy dla uchodźców korzystne.

Stosunkowo chłodny stosunek do migrantów jest pochodną pewnych obaw, które żywią i artykułują respondenci. Czego zatem najbardziej obawiają się Polacy ze strony uchodźców? Najwięcej obaw odnotowujemy na następujących płaszczyznach:

- stawiania interesów swojego kraju nad interesem kraju, do którego przybyli (77\% wskazań, gdy tymczasem w przypadku reszty państw jest to $85-91 \%$ ),

— lojalności - w sytuacji wojny lub konfliktu — względem swojego kraju, nie zaś kraju, który ich przyjął (76\% wskazań, inne kraje to $80-87 \%)$,

- zmiany sposobu życia polskiego społeczeństwa związanej z przybyciem i wzrostem liczby imigrantów (57\%, inne nacje to $77-84 \%$ ),

- zabierania przez imigrantów pracy mieszkańcom kraju (54\%, inne kraje 61-66\%).

W porównaniu ze Słowakami, Węgrami i Czechami Polacy stosunkowo mało obawiają się natomiast:

— zatracenia własnej kultury (44\%, inne kraje to wskazania 65-73\%),

- roznoszenia przez imigrantów nietypowych chorób (46\%, inne państwa to już 79-84\%),

- wzrostu przestępczości (49\%, inne kraje 62-78\%).

Szczegółowe wyjaśnienie różnic pomiędzy wskazaniami Polaków a innych społeczeństw Grupy Wyszehradzkiej przekracza ramy niniejszego artykułu. Ważne wydają się tu być jednak nie tylko usytuowania geopolityczne krajów i doświadczenia historyczne społeczeństw, sytuacja narodowościowa i udział w niej mniejszości. Istotny jest aktualny kontekst polityczny, kolosalnego znaczenia, mimo rozwoju sieci, odbierają nabierają media. Nie można wreszcie abstrahować od doświadczeń samego roku 2015 r., związanych z „interakcjami” mieszkańców z uchodźcami.

\section{Uchodźcy w opiniach Polaków}

Wzrost zainteresowania wielokulturowością, ale także otwartości Polaków na szeroko rozumianych ,innych" obrazują badania sondażowe realizowane m.in. przez CBOS. Przyjrzyjmy się stosunkowi Polaków do cudzoziemców pełniących potencjalnie różne role społeczne w $1999 \mathrm{r}$. oraz w $2015 \mathrm{r}^{29}$ Co do tego, aby cudzoziemiec został najbliższym sąsiadem, nie wyrażało zastrzeżeń w 2015 r. 88\% badanych, natomiast w 1999 r. było to 74\% respondentów. Cudzoziemca jako bliskiego współpracownika akceptuje obecnie 86\% (wcześniej 71\%) badanych, zaś jako szefa $78 \%$ (w roku 1999 - 60\%). Podobny wzrost akceptacji widoczny jest w przypadku ról zawodowych. Może być on lekarzem wedle $82 \%$ uczestników

${ }^{29}$ Przybysze z bliska i daleka, czyli o imigrantach w Polsce, 2015, nr 93. CBOS, czerwiec 2015. 
badania (wcześniej 69\%), nauczycielem dziecka respondenta 78\% (analogicznie $63 \%$ ), czy nawet księdzem w parafii - 76\% (wcześniej było to tylko 53\%). Poza wzrostem akceptacji dla innych istotna jest jeszcze jedna kwestia - osoby, które znają przedstawicieli innych nacji, korzystniej wypowiadają się na temat pełnienia przez nich różnych ról społecznych, są bardziej otwarte względem nich. Wyniki tych sondaży potwierdzają zatem wnioski formułowane na bazie innych badań, w tym badań eksperymentalnych — intensyfikacja interakcji z „innymi” prowadzi do zwiększenia akceptacji w stosunku do nich.

Jakie nacje Polacy akceptowaliby w swoim kraju? Najkorzystniejsza dla Polski wedle respondentów jest obecność w kraju Amerykanów, Czechów oraz Niemców (50-52\% wskazań pozytywnych). Dość korzystnie Polacy oceniają także obecność w Polsce Ukraińców (pozytywnie - 38\% wskazań, niekorzystnie - 37\%, brak wskazań $-27 \%)$. W przypadku przedstawicieli innych grup i narodów oceny negatywne przeważają nad pozytywnymi. Przewaga ocen negatywnych jest stosunkowo mała w przypadku Wietnamczyków, Białorusinów, Rosjan (od 4 do $10 \%$ ), w przypadku Afrykanów wzrasta jednak już do 14\%, Turków - do 32\%, zaś Arabów do $48 \%$ wskazań, iż ich obecność w Polsce jest niekorzystna dla kraju ${ }^{30}$. Generalnie zatem akceptowani są ,,inni”, którzy są podobni etnicznie i rasowo, ale także kulturowo. To zarówno sąsiedzi, z którymi Polacy mogą mieć stosunkowo częste kontakty, jak i najprawdopodobniej znani nie tyle z relacji interpersonalnych Amerykanie. Oczywiście pytaniem otwartym pozostaje to, czy ów przedstawiciel amerykańskiego społeczeństwa, którego Polacy chętnie widzieliby u siebie, to przedstawiciel białej klasy średniej, czy raczej ktoś posiadający inny kolor skóry? Nieco inaczej jest w przypadku sąsiadów zza wschodniej granicy kraju, ale także „innych” kulturowo, etnicznie i rasowo. Będzie to o tyle istotne, że migranci przybywający do Europy w 2015 r. będą osobami, które właśnie na tych płaszczyznach różnią się od ogółu Polaków.

Migranci przybywający do Europy spoza kontynentu określani są różnymi terminami. Pomijając wszelkie zwroty nacechowane emocjonalnie i negatywnie wartościujące przybyszy, są to zatem „emigranci”, czy nawet „emigranci ekonomiczni” bądź też „uchodźcy”. Nawet stosowanie terminów neutralnych badawczo ma jednak określone konotacje emocjonalne. Emigrant opuszcza swój kraj niesiony chęcią polepszenia swojego bytu - warunki materialne, jakość życia, możliwości rozwoju w jego państwie są nieatrakcyjne, dlatego też podejmuje on decyzję o tym, aby je opuścić na stałe (emigracja definitywna) lub na określony czas (emigracja czasowa). Uchodźca kierowany zagrożeniem zdrowia i życia jest niejako zmuszony do tego, aby opuścić swoje miejsce zamieszkania - pozostanie $\mathrm{w}$ nim wiązałoby się dla niego z realnym zagrożeniem.

Przez wiele lat problem migracji w Polsce istniał raczej w kontekście opuszczania kraju przez Polaków, głównie młodych, podejmujących w innych krajach

${ }^{30}$ Ibidem. 
naukę lub też pracę zarobkową. Nic więc dziwnego, że przed cyklicznymi badaniami realizowanymi w roku $2015 \mathrm{r}$. kwestia ta pojawiała się w badaniach CBOS bez mała dekadę wcześniej.

Kryzys migracyjny, mediatyzacja zagadnienia i uczynienie z niego problemu społecznego, podejmowane próby rozwiązania, a także polityzacja kwestii, determinują zasadność badań sondażowych w tym zakresie. Ponieważ ośrodek demoskopijny posiłkuje się w nich terminem „uchodźcy”, stąd też prezentowane w tym miejscu badania empiryczne dotyczące właśnie tej kategorii osób.

Pierwszy komunikat ośrodka demoskopijnego poświęcony literalnie problematyce uchodźców pochodzi z maja $2015 \mathrm{r}^{31}$, a jego konkluzje trudno jest uznać za zaskakujące. Na pytanie: „Czy [...] Polska powinna przyjmować uchodźców z krajów objętych konfliktami zbrojnymi?" pozytywnie odpowiadało wtedy blisko $3 / 4$ badanych (72\% wskazań). Jedna piąta była przeciwnego zdania (21\%). Warto podkreślić zbieżność wskazań w stosunku do wyników podobnego badania sprzed dekady ${ }^{32}$.

Badania przeprowadzone w sierpniu, wrześniu i październiku pokazują generalnie ogólne zmniejszanie się odsetka osób, które są za bezwarunkowym (przyjmowanie tych, którzy są zainteresowani) lub warunkowym (przyjmowanie jedynie do czasu możliwości powrotu do kraju) przyjmowaniem do Polski uchodźców. Zmniejsza i stabilizuje się odsetek osób, które nie wybierają wskazania kierunkowego, wzrasta natomiast odsetek tych, którzy uznają, że Polska nie powinna przyjmować uchodźców ${ }^{33}$.

Badanie zrealizowane w styczniu 2016 r. pokazuje, że względna stabilizacja wskazań miała miejsce jedynie w okresie od sierpnia do października. Negatywny stosunek do uchodźców deklaruje już ponad połowa (53\%) respondentów, na ich przybycie godzi się $44 \%$ zapytanych, przy czym w zdecydowanej większości są to osoby, które deklarują jedynie otwartość warunkową, ograniczoną na czas ustania na danym terenie konfliktu i możliwości powrotu „innych” do ich kraju.

Próba rekonstrukcji zmiany postaw względem uchodźców w polskim społeczeństwie z pewnością nie odnosi się do nagłej zmiany w tym zakresie, polegającej na przybyciu w okresie pomiędzy poszczególnymi badaniami do kraju ich sporej grupy. Skoro kontakty bezpośrednie nie są tu najprawdopodobniej czynnikiem istotnym, musimy zmiany postaw upatrywać w innym miejscu. Wydaje się, że zasadnicze znaczenie będą miały tu informacje o wydarzeniach zachodzących na terenie państw Unii Europejskiej, zapośredniczone przez przekazy medialne. Zamachy w Paryżu oraz próby poszukiwania osób zaangażowanych w śmierć ludności cywilnej w Brukseli, informacje medialne i relacje w mediach społecznościowych dotyczące napadów na kierowców samochodów ciężarowych, a w styczniu także

${ }^{31}$ Polacy wobec problemu uchodźctwa, 2015, nr 81, CBOS, Warszawa, czerwiec 2015.

${ }^{32}$ Opinie ludności z krajów Europy Środkowej o imigrantach i uchodźcach, BS 2005, nr 60, CBOS, Warszawa, marzec 2005.

${ }^{33}$ Polacy o uchodźcach w Internecie i w „Realu”, 2015, nr 149, CBOS, październik 2015. 


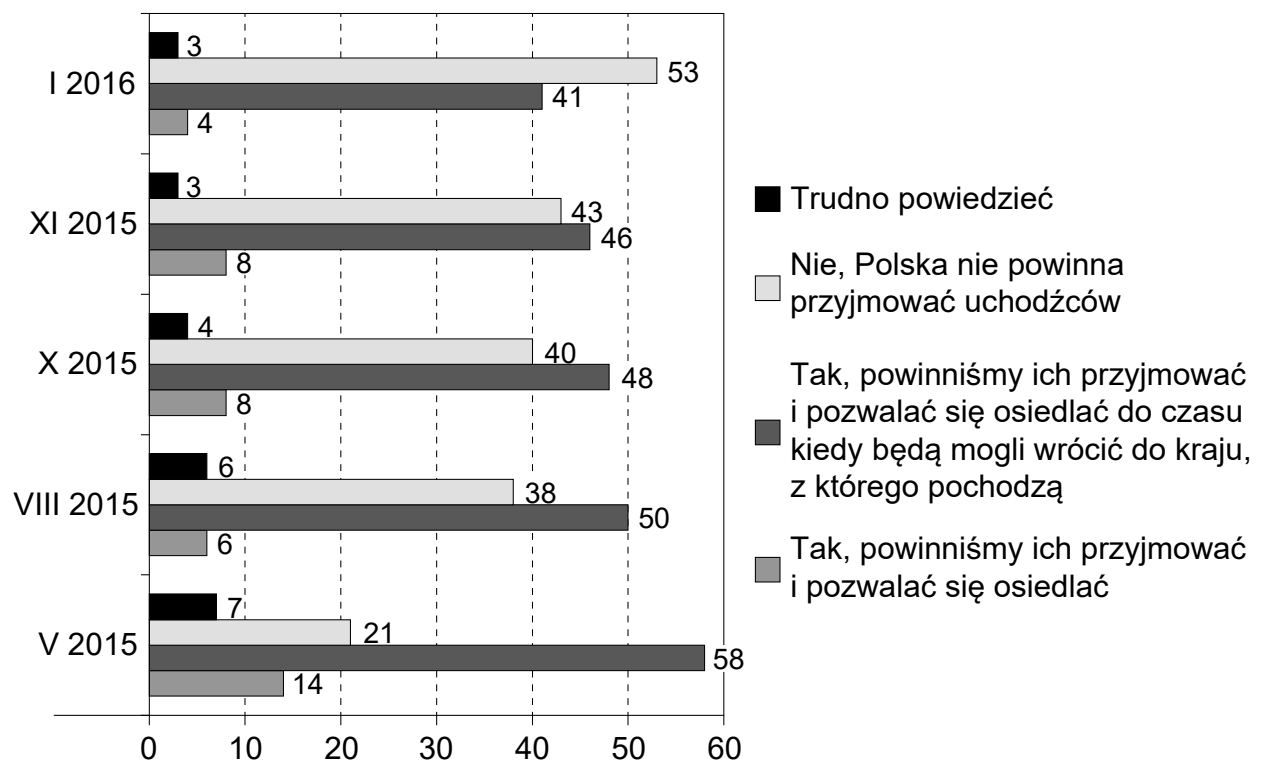

Wykres 1. Opinie Polaków na temat przyjmowania do Polski uchodźców

Źródło: opracowanie własne na podstawie: Polacy o uchodźcach w Internecie i w „Realu” 2015, nr 149, CBOS, październik 2015 oraz Stosunek Polaków do przyjmowania uchodźców 2016, nr 12, CBOS, styczeń 2016, Stosunek do uchodźców po atakach terrorystycznych w Paryżu 2015, nr 172.

na mieszkańców miasta Calais, leżącego przy francusko-brytyjskiej granicy, seria ukrywanych przez społecznie odpowiedzialne media w Niemczech napadów na kobiety w sylwestrową noc, a kilka dni później — analogiczne doniesienia płynące z innych metropolii europejskich - to tylko najbardziej spektakularne przykłady. Katalizatorem były także ukazujące się i popularne w Internecie, acz zajmujące stosunkowo mało miejsca w mediach masowych informacje o napadach, gwałtach i rozbojach, czy nawet zabójstwach dokonywanych przez osoby należące do mniejszości etnicznych. W poszczególnych państwach narodowych pojawiały się także deklaracje, czy nawet inicjatywy sprowadzające się do ograniczenia kontaktów, fizycznego „odgrodzenia się”, czy też zamknięcia na migrantów.

Z perspektywy socjologii nie tylko istotne są „uśrednione” postawy społeczne względem jakiegoś obiektu, ale także to, jakie cechy charakteryzujące jednostki wpływają na ich wskazania. Zmienną niezależną, która nie różnicowała wskazań respondentów, była płeć, co oznacza, że ogólnie stosunek kobiet i mężczyzn do problemu uchodźctwa był zbliżony. Inaczej było z wiekiem. Wbrew pozorom nie mamy tu do czynienia z sytuacją, w której młodzi ludzie, wychowani w otwartym świecie Unii Europejskiej, są tolerancyjni dla obcych, zaś starsi, ci, którzy należą do pokolenia rezydentów zamkniętego na kontakty państwa, są przywiązani do silnej niechęci względem obcych. Tu właśnie młodsi respondenci zdecydowanie częściej byli przeciwnikiem przyjmowania uchodźców z krajów objętych konflik- 
tami zbrojnymi. Wśród najmłodszych respondentów takie wskazania wybrało $65 \%$ najmłodszych uczestników badania (18-24 lata) oraz 66\% tych nieco starszych (25- i 34-letnich). Osoby, które przekroczyły 45 rok życia, rzadziej opowiadały się przeciw przyjmowaniu uchodźców (w zależności od przedziału wiekowego wskazania 44-45\%). Jeśli chodzi o miejsce zamieszkania, to najmniej otwartą postawę względem uchodźców wojennych, ale także cudzoziemców mających trafić do Polski w wyniku realokacji z innych państw UE sygnalizowali mieszkańcy wsi, najbardziej otwartą - mieszkańcy największych miast. Generalnie wraz ze wzrostem wykształcenia spadała liczba przeciwników przyjęcia uchodźców (wśród osób $\mathrm{z}$ wykształceniem podstawowym lub gimnazjalnym przeciwnikami przyjmowania uchodźców wojennych było $66 \%$ badanych, wśród osób o wykształceniu wyższym ten odsetek wynosił zaledwie 33\%). Sceptycznie do innych odnosili się robotnicy niewykwalifikowani, gospodynie domowe oraz renciści. Przeciwników najmniej było natomiast wśród kadry kierowniczej i specjalistów z wyższym wykształceniem oraz emerytów. Akceptacja dla uchodźców wzrastała generalnie wraz z dochodem respondenta, a także subiektywną oceną sytuacji materialnej jego gospodarstwa domowego. Bardziej otwarte na obcych były także również osoby, które deklarowały poglądy lewicowe, a nie prawicowe ${ }^{34}$.

\section{„Uchodźcy" w badaniach jakościowych}

Cechą badań ilościowych jest porównywalność wyników, możliwość śledzenia trendów, otrzymywanie wyników, które mogą być następnie z pewnym prawdopodobieństwem rozszerzone na całość populacji. Specyfikę badań jakościowych kreśli zaś ich unikalność, „głębia” i swoistośćc ${ }^{35}$. Ograniczeniem technik korzystających z wywiadu jest natomiast to, że część respondentów może wybierać pewne wskazania, kierując się polityczną i społeczną poprawnością czy konformizmem. Inaczej jest, kiedy „respondenci” wypowiadają się na jakieś tematy, nie wiedząc, że de facto stają się uczestnikami badania. Dlatego też obok badań reaktywnych (takich jak zaprezentowane powyżej badania sondażowe) socjologia dysponuje także możliwością prowadzenia badań niereaktywnych, czyli takich, w których nie inicjuje się powstawania materiału empirycznego, analizuje się jedynie ten, który jest dostępny dla badaczy.

Współcześnie do tradycyjnych form ekspresji, jakimi były listy czy pamiętniki, dodać możemy także wypowiedzi zamieszczane w sieci. Mają one szereg zalet. Zwraca się uwagę na to, że analiza internetowych forów stwarza badaczom szansę obserwowania dyskursów dotyczących niekiedy zakulisowych wymiarów życia

${ }^{34}$ Por. Aneks do: Stosunek Polaków do przyjmowania uchodźców, 2016, nr 12, CBOS, styczeń 2016.

${ }^{35}$ Por. W. Sitek, Między rynkiem a civil society; konteksty badań socjologicznych, Warszawa 2007. 
społecznego. Internet jest „miejscem”, które wiąże się z poczuciem anonimowości, pozwala dotrzeć do wypowiedzi pojawiających się w rozmowach bezpośrednich tylko w grupach pierwotnych; w sytuacji wywiadu socjologicznego trudne - jeśli nie niemożliwe - byłoby uzyskanie właściwego poziomu zaufania uczestnika badania $^{36}$.

O ile jednak możemy mówić o poczuciu anonimowości w sytuacji, kiedy toczy się dyskusja o mankamentach szkolnictwa wyższego, stosunku funkcjonariuszy Policji do policjantek, macierzyństwie czy działaniu straży miejskiej, o tyle trudno ową wolność wypowiedzi przenieść na wymiar dyskusji o uchodźcach. Zarówno niektóre media, jak i instytucje państwowe wpływały w różny sposób na powstawanie tego niewywoływanego przez badacza materiału empirycznego. Brak możliwości komentowania treści dotyczących uchodźców na niektórych portalach internetowych (m.in. na portalu Gazety Wyborczej), publiczne zapowiedzi prokuratury co do uważnego nadzoru zawartości sieci ${ }^{37}$, aktywność różnych organizacji pozarządowych ${ }^{38}$ i informacje o dochodzeniach przeciwko internautom ${ }^{39}$ mogły wpłynąć na samokontrolę ekspresji części osób, inne wypowiedzi zaś wyeliminować. Zdając sobie sprawę z faktu, że statystyczny internauta nieco różni się od statystycznego uczestnika badania sondażowego ${ }^{40}$, wydaje się, że świat widziany oczyma internautów jawi się inaczej niż ten rysowany na bazie zestandaryzowanych wywiadów.

W październiku 2015 r., wtedy, kiedy w badaniu sondażowym 54\% respondentów deklarowało warunkowe lub bezwarunkowe przyjęcie do Polski uchodźców z krajów ogarniętych wojną ${ }^{41}$, analizie poddano także treści obecne w polskim Internecie dotyczące uchodźców, imigrantów oraz osób ubiegających się o azyl. Na wybranych 1000 wpisach przeprowadzono badanie jakościowe. Ponad połowa wpisów (548) wyrażała opinie internautów wobec kryzysu i uchodźców, pozostałe treści miały charakter informacji lub pytań niewskazujących stosunku autora do kwestii. Wśród wpisów wyrażających opinię jedynie nieliczne (6\%) miały wymiar pozytywny dla uchodźców, stosunkowo mało było także wpisów neutralnych

${ }^{36}$ K. Dojwa, Kobiety w policji: wybrane aspekty historyczno-socjologiczne w kontekście stużby kobiet $w$ formacjach mundurowych $w$ Polsce, [w:] Kobiety, feminizm, demokracja: wybrane zagadnienia z seminarium IFiS PAN z lat 2001-2009, red. B. Budrowska, Warszawa 2009, s. 156-172.

37 Jak czytamy: ,Walkaz rasizmem, w tym w internecie to jeden z priorytetów Prokuratora Generalnego Andrzeja Szeremeta”, por. M. Jałoszewski, Andrzej Seremet:Będzieśledztwo za wpisyo „Auschwitz - idealnym pensjonacie dla uchodźców", 5.09.2015, http://wyborcza.pl/1,75478,18715456, andrzej-seremet-bedzie-sledztwo-za-wpisy-o-auschwitz-idealny.html\#ixzz3zf2d6EZ8 (dostęp: 9 lutego 2016).

38 A. Gmiterek-Zabłocka, Wrześniowy pik w zgłoszeniach mowy nienawiści. „90 proc. dotyczy internetu. Już nie to, że sq wulgarne. Łamiq Kodeks Karny”, 2.11.2015, http://www.tokfm.pl/Tok $\mathrm{fm} / 1,103454,19127446$,wrzesniowy-pik-w-zgloszeniach-mowy-nienawisci-90-proc-dotyczy.html, (dostęp: 9 lutego 2016).

${ }^{39}$ Po tekście „Wyborczej”. Prokuratura wszczęła dochodzenie ws. rasistowskich wpisów o uchodźcach, 8.09.2015, http://wyborcza.pl/1,75478,18736543,po-tekscie-wyborczej-prokuratura-wszczela-dochodzenie-ws.html\#ixzz3zf3slfMp, (dostęp: 9 lutego 2016).

${ }^{40}$ Internauci 2015, nr 90, CBOS, Warszawa, czerwiec 2015.

${ }^{41}$ Polacy uchodźcach w Internecie i w „Realu”, 2015, nr 149, CBOS, listopad 2015. 
(13\%), co oznacza wyraźną dominację postaw negatywnych (81\%). Negatywne wpisy pozwoliły wyodrębnić główne płaszczyzny krytyki obcych. Odnosiły się one do:

— odmiennej religii i kultury,

- chorób,

- stanowiska polskiego rządu,

- sytuacji w Niemczech,

- wykorzystywania przez uchodźców świadczeń socjalnych,

- stanowiska Unii Europejskiej.

Konkluzje autorów raportów wskazują na: rozdźwięk między treściami wypowiedzi badanych oraz tych, które zamieszczane są w Internecie, istnienie krytycznych postaw obecnych $\mathrm{w}$ sieci i postaw bardziej stonowanych $\mathrm{w}$ trakcie realizacji wywiadów, emocji, których nie zaprezentuje żaden kwestionariusz, i wreszcie to, że „strach jest dominującą postawą prezentowaną w mediach społecznościowych"ł2.

Na początku lutego w lokalnym serwisie Gazety Wyborczej ukazał się artykuł zatytułowany Studenci $z$ Wrocławia widza w Arabach terrorystów. Zaskakujące wyniki badan $\hat{n}^{43}$. W artykule przedstawiono badania syryjskiego socjologa od lat mieszkającego w Polsce, zrealizowane z udziałem wrocławskich studentów. Wybrane wyniki badań zaprezentowano na wykresach poniżej. Pierwszy z wykresów przedstawia wyniki badań w sytuacji jawnych deklaracji respondentów, drugi natomiast odnosi się do wyników badań anonimowych.

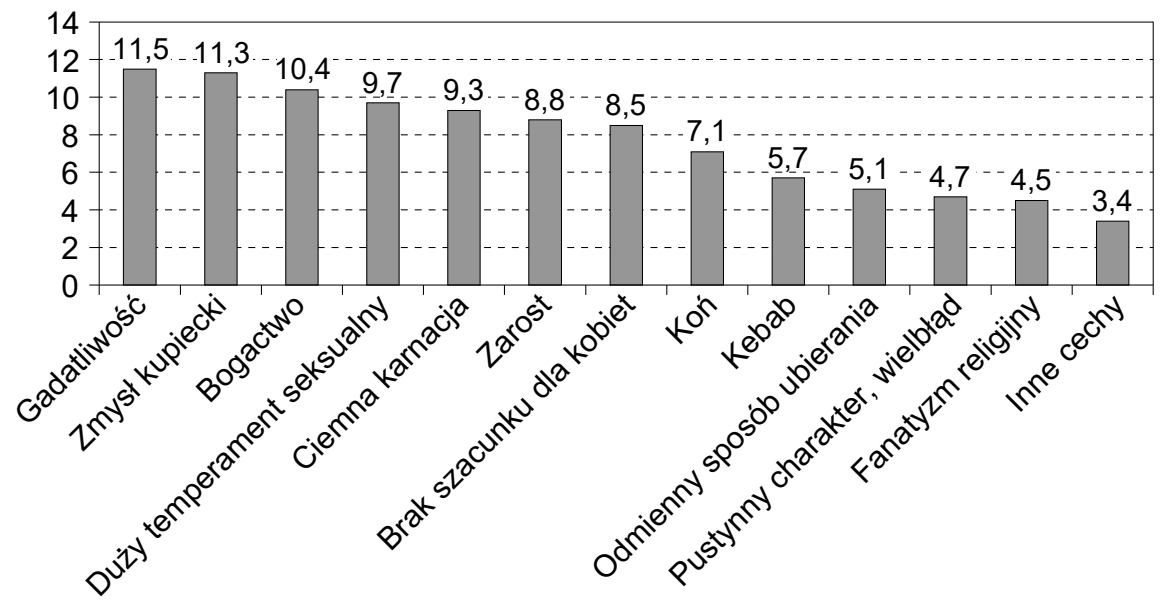

Wykres 2. Skojarzenia studentów dotyczące Arabów (jawne)

Źródło: opracowanie własne na podstawie N. Sawka, Studenci $z$ Wrocławia widza w Arabach terrorystów. Zaskakujace wyniki badań [DANE], 2.02.2016, http://wroclaw.wyborcza.pl/wroclaw/1,35771,19567985,studenci-z-wroclawia-widza-w-arabach-terrorystow-zaskakujace.html\#ixzz3zH1VK2oc (dostęp: 5 lutego 2016).

${ }^{42}$ Ibidem.

${ }^{43}$ N. Sawka, Studenci $z$ Wrocławia widza w Arabach terrorystów. Zaskakujące wyniki badań [DANE], 2.02.2016, źródło: http://wroclaw.wyborcza.pl/wroclaw/1,35771,19567985,studenci-z-wroclawia-widza-w-arabach-terrorystow-zaskakujace.html\#ixzz3zH1VK2oc, (dostęp: 5 lutego 2016). 


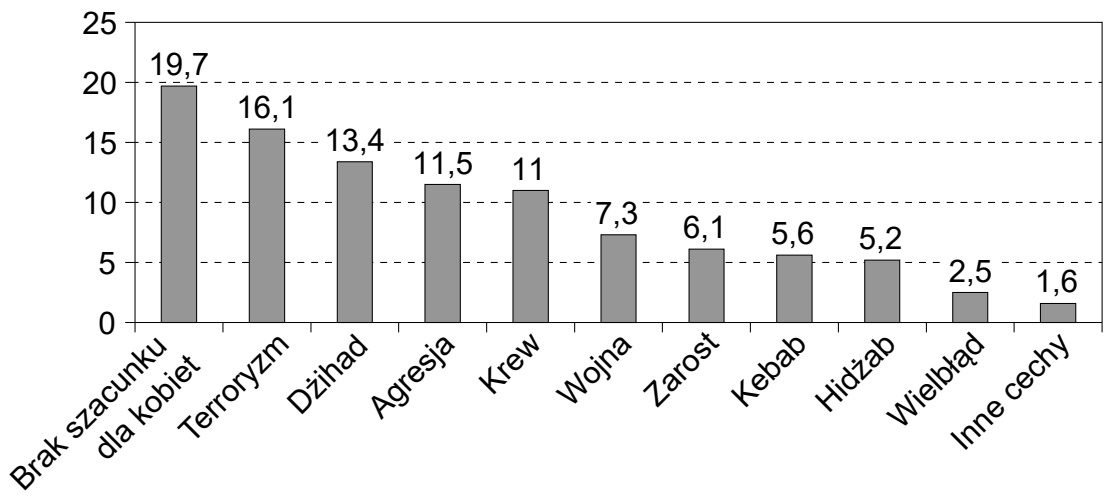

Wykres 3. Skojarzenia studentów dotyczące Arabów (anonimowe)

Źródło: opracowanie własne na podstawie N. Sawka, Studenci $z$ Wrocławia widza w Arabach terrorystów. Zaskakujace wyniki badań [DANE], 02.02.2016, http://wroclaw.wyborcza.pl/wroclaw/1,35771,19567985,studenci-z-wroclawia-widza-w-arabach-terrorystow-zaskakujace.html\#ixzz3zH1VK2oc (dostęp: 5 lutego 2016).

Nawet pobieżna interpretacja powyższych wyników prowadzi nas do wniosku, że w jawnych deklaracjach studenci w Arabach widzą przede wszystkim przedstawicieli innej kultury, różniących się zachowaniem, komunikacją, stylem życia etc. W świetle wypowiedzi anonimowych Arabów należy się obawiać: nie szanują oni kobiet, zaś zasadnicze rysy ich wizerunku kreuje agresja.

Zaprezentowane $\mathrm{w}$ artykule prasowym główne wnioski z wyników badań empirycznych dotyczą nikłej znajomości bezpośredniej Arabów, wyższej frekwencyjności postaw przeciw przyjmowaniu uchodźców do Polski niż postaw „otwartych”, dostrzegania poważnych różnic kulturowych pomiędzy Polakami a przedstawicielami świata islamu, skojarzeń związanych z terroryzmem i zagrożeniem.

Otwarcie przez portal możliwości wypowiedzi internautów na forum zaowocowało dyskusją, acz precyzyjniej byłoby wskazać raczej na fakt możliwości ekspresji, nie zaś wymiany opinii pomiędzy użytkownikami sieci. W ciągu trzech $\mathrm{dni}^{44}$ na portalu pojawiło się łącznie 96 wpisów, co - biorąc pod uwagę lokalną specyfikę tego konkretnego portalu — jest liczbą dość pokaźną. Wskazywane wcześniej badania operowały na bardziej rozbudowanym materiale empirycznym, natomiast zaletą analizy jakościowej wpisów zawartych pod tą publikacją jest to, że ogniskuje się ona wokół konkretnej kwestii — badań empirycznych, które ukazują wrocławskich studentów jako osoby nieprzychylnie odnoszące się do przedstawicieli wyznawców islamu. Sam tytuł sugerował fenomen owych wskazań, co $\mathrm{z}$ resztą znalazło także swoje odniesienia $\mathrm{w}$ wypowiedziach internautów.

$\mathrm{Na}$ forum przeważają osoby, które krytycznie odnoszą się do Arabów, postawy neutralne są praktycznie nieobecne, ci, którzy deklarują do nich swój przychylny

${ }^{44}$ Obserwację forum zakończono 5 lutego 2016, godz. 9.00 
stosunek, są nieliczni, poza tym - ich wypowiedzi są negatywnie oceniane przez czytelników forum. Osoby deklarujące swój pozytywny stosunek do obcych piszą głównie o tym, że są oni niemal nieobecni w Polsce, że obawy przed nimi są pochodną stereotypów, odnoszą się do nikłych kompetencji studentów i ich podatności na manipulację, obaw o konkurencję na rynku pracy, ale także konotacji patriotyczno-politycznych.

Wpisy krytykujące politykę otwartości na inne kultury są zdecydowanie liczniejsze. Bardzo częstym motywem jest sarkastyczne komentowanie wyników badań, następnie zaś wskazywanie na rozmaite przesłanki wpływające na wskazania studentów. Są zatem wśród nich:

- kwestie związane z odmiennością kulturową, odnoszone także do płaszczyzny ekonomicznej (oczekiwania uchodźców na pomoc socjalną, nieorientowanie się ku aktywności zawodowej i zarobkowej),

- obawy o bezpieczeństwo swoje i najbliższych, ale także „zamknięcie” na obcych z powodu obaw o bezpieczeństwo (takim zagrożeniem byłyby zamachy terrorystyczne),

- powoływanie się na przekazy medialne i doświadczenia innych krajów Zachodu, które przyjęły do siebie znaczącą pulę uciekinierów (Niemcy, Francja),

- przywoływanie własnych doświadczeń, kiedy to internauci mieszkali w państwach, w których liczebność migrantów jest wyższa,

- propagandowy i manipulacyjny charakter materiału prasowego, a także stawianie pytań o faktyczne postawy samych dziennikarzy.

$\mathrm{W}$ prezentowanych wcześniej badaniach sondażowych widoczny jest spadek akceptacji dla przyjmowania uchodźców do Polski. Natomiast próby wykorzystania do rekonstrukcji wizerunku potencjalnych przybyszy metod i technik jakościowych pokazują nie tylko zasięg i wymiary krytyki otwarcia na migrantów, ale także wieloaspektowe obawy co do nich. Jeśli weźmiemy pod uwagę toczące się śledztwa przeciwko osobom artykułującym w Internecie negatywne treści pod adresem uchodźców, względną mediatyzację zgłoszeń takich wypowiedzi do organów ścigania, zaczynamy się zastanawiać, jakie wypowiedzi miałyby miejsce, gdyby tego ograniczenia nie było...

Wyniki badań empirycznych jakościowych i ilościowych nie mogą być oczywiście porównywane, niemniej intencją ich przytoczenia było pokazanie swoistości, ale także zalet i ograniczeń poszczególnych metod i technik badawczych. Blisko trzy dekady temu A. Sułek, mówiąc o badaniach sondażowych realizowanych w okresie PRL, podkreślał m.in. fakt, iż badanie sondażowe to określona sytuacja społeczna, w której dochodzi do interakcji badacza i respondenta. „Ujęte w tej perspektywie odpowiedzi badanego nie przestają być reakcjami na treść pytań, ale okazują się obciążone wpływem badacza, osobowości badanego, różnych składników sytuacji psychospołecznej badania i kontekstu globalnego"35. Dekadę później,

${ }^{45}$ A. Sułek, Ogród metodologii socjologicznej, Warszawa 2002, s. 48. 
a także w dalszych latach W. Sitek podkreślał, iż badania społeczne (w tym szczególnie badania sondażowe) mają sens wtedy, kiedy respondenci mają zaufanie do ośrodków demoskopijnych i badaczy, nie obawiają się wskazywania swoich racji, dzielą się swymi opiniami. Konstruując fundamentalne twierdzenia teorii upodmiotowionego obywatela racjonalnego w kontekście prognoz przedwyborczych ${ }^{46}$, wskazywał na atrybuty nader istotne także w przypadku innych badań dotyczących sfery publicznej.

Zaprezentowane powyżej badania jakościowe mają charakter wycinkowy, niemniej płynące z nich konkluzje z pewnością nie ograniczają się jedynie do „pogłębienia” wizerunku przedstawicieli innych kultur i nacji wśród Polaków.

\section{Zakończenie}

Przez wiele lat Polacy w świetle rozmaitych badań ilościowych prezentowali się jako społeczeństwo generalnie otwarte na uchodźców, coraz korzystniej postrzegające swoich dalszych i bliższych sąsiadów, czerpiące z kulturowego wymiaru integracji europejskiej. Autorzy badań jakościowych wskazywali niekiedy na fasadowy i płaskoempiryczny, deklaratywny stosunek do innych. Nie negując wyników badań i ich interpretacji oraz odnosząc się do charakterystyki socjologii ilościowej zbierającej materiał empiryczny za pomocą wywiadów, można jednak przyjąć, że skoro Polacy w świetle badań sondażowych prezentowali się jako osoby otwarte na cudzoziemców, to czynili tak dlatego, że uznawali taką postawę za premiowaną pozytywnie, pożądaną.

Wyniki kolejnych edycji Europejskiego Sondażu Społecznego (2002-2012) pokazywały pozytywny stosunek Polaków do innych, dość wysoką akceptację dla przyjmowania do kraju osób, które chcą się tu osiedlić i żyć. Wprawdzie badania zaczęto realizować w 2002 r., niemniej od czasu wejścia Polski do UE ta akceptacja wzrastała i uległa stabilizacji. Oczywiście sam akt akcesji ma tu znaczenie symboliczne - istotne wydaje się funkcjonalne otwarcie granic, swoboda poruszania się, wyjazdy Polaków, w tym szczególnie wyjazdy o wymiarze zarobkowym, które sensu stricto doprowadziły także do poznawania przez Polaków innych kultur. Wstępne wyniki badań sondażowych Europejskiego Sondażu Społecznego pokazują, że w 2015 r. ta szeroko rozumiana „otwartość” Polaków na obcych maleje, niemniej negatywna zmiana stosunku mieszkańców Europy do przybyszy będzie widoczna także w innych społeczeństwach. W świetle ogólnopolskich badań sondażowych na plan pierwszy wysuwa się generalnie stabilny przez wiele lat stosunek do migrantów, ulegający wyraźnej zmianie wraz z nasileniem się kryzysu uchodźczego oraz incydentów z udziałem przedstawicieli innych nacji i kultur

${ }^{46}$ W Sitek, Przyczynek do teorii upodmiotowionego obywatela racjonalnego. Przewidywanie wyników w perspektywie metodologicznej, [w:] Czy można przewidzieć? Socjologiczno-metodologiczne doświadczenia polskich badań przedwyborczych, red. W. Sitek, Wrocław 1995. 
pozaeuropejskich. Zamachy terrorystyczne, przestępstwa, czy nawet roszczeniowe postawy przybyszy będą silnie rzutować na otwartość Polaków na innych oraz chęć przyjęcia ich do swego państwa. Szczególnie widoczne będzie to w wypowiedziach zamieszczanych w sieci.

Niniejszy artykuł ma charakter przyczynkowy, zarówno Unia Europejska, jak i „lokalne” polityki poszczególnych państw będą kreślić jego kontynuację, a wpływ na to, co o migrantach myślą mieszkańcy poszczególnych społeczeństw europejskich, w tym też Polski, wywierać będą także sami przybysze.

\section{Bibliografia}

Andrejuk K., Postawy wobec imigrantów świetle wyników Europejskiego Sondażu Społecznego 20142015. Polska na tle Europy, „European Studies Unit” 2015, nr 2 (Warszawa, grudzień 2015).

Babbie E., Badania spoleczne w praktyce, Warszawa 2004.

Biedaka B., Osadnictwo polonijne w ośrodkach miejskich na pótnocno-wschodnim wybrzeżu Stanów Zjednoczonych Ameryki Pótnocnej (1870-1914), [w:] Migracje i społeczeństwo. Zbiór studiów, [red.?], Warszawa 1995.

Dębicki M., Makaro J., Polacy wobec Ukrainy i Ukraińców w latach 2012-2014 - refleksje na marginesie badań sondażowych, [w:] Sąsiedztwa III RP - Ukraina. Zagadnienia społeczne, red. M. Dębicki, J. Makaro, Wrocław 2015.

Dojwa K., Kobiety w policji: wybrane aspekty historyczno-socjologiczne w kontekście stużby kobiet $w$ formacjach mundurowych $w$ Polsce, [w:] Kobiety, feminizm, demokracja: wybrane zagadnienia $z$ seminarium IFiS PAN z lat 2001-2009, red. B. Budrowska, Warszawa 2009.

Dulczewski Z., Sprawa polska w biografii i twórczości Floriana Znanieckiego, [w:] Socjologia polityczna Floriana Znanieckiego a współczesna polityka, red. O. Sochacki, Gdańsk 1996.

Florczak A., Uchodźcy, [w:] Encyklopedia politologii, red. M. Żmigrodzki, t. 5: Stosunki międzynarodowe, Kraków 2002.

Frysztacki K., Socjologia problemów społecznych, Warszawa 2010.

Hałas E., Znaczenia i wartości społeczne. O socjologii Floriana Znanieckiego, Lublin 1991.

Kobiety, feminizm, demokracja: wybrane zagadnienia z seminarium IFiS PAN z lat 2001-2009, red.

B. Budrowska, Warszawa 2009.

Leksykon polityki społecznej, red. B. Rysz-Kowalczyk, Kraków 2001.

Migracje i społeczeństwo. Zbiór studiów, red. J.E. Zamojski, Warszawa 1995.

Nalewajko M., Migracje: ewolucja zjawiska, [w:] Migracje i społeczeństwo. Zbiór studiów, [red.??], Warszawa 1995.

Olechnicki K., Załęcki P., Słownik socjologiczny, Toruń 1997.

Polska-Europa. Wyniki Europejskiego Sondażu Społecznego 2002-2012, red. P.B. Sztabiński, F. Sztabiński, Warszawa 2014.

Sąsiedztwa III RP - Ukraina. Zagadnienia społeczne, red. M. Dębicki, J. Makaro, Wrocław 2015.

Sinclair U., Grzęzawisko, tłum. A. Niemojewski, Warszawa 1907.

Sitek W., Między rynkiem a civil society; konteksty badań socjologicznych, Warszawa 2007.

Sitek W., Przyczynek do teorii upodmiotowionego obywatela racjonalnego. Przewidywanie wyników w perspektywie metodologicznej, [w:] Czy można przewidzieć? Socjologiczno-metodologiczne doświadczenia polskich badań przedwyborczych, red. W Sitek, Wrocław 1995.

Socjologia polityczna Floriana Znanieckiego a wspótczesna polityka, red. O. Sochacki, Gdańsk 1996. Sułek A., Ogród metodologii socjologicznej, Warszawa 2002.

Sztabiński P.B., Dlaczego Europejski Sondaż Społeczny, [w:] Polska-Europa. Wyniki Europejskiego Sondażu Społecznego 2002-2012, red. P.B. Sztabiński, F. Sztabiński, Warszawa 2014. 
Wysieńska K., Opinia publiczna wobec kwestii napływu cudzoziemców, [w:] Polska-Europa. Wyniki Europejskiego Sondażu Społecznego 2002-2012, red. P.B. Sztabiński, F. Sztabiński, Warszawa 2014.

Zamojski J.E., Migracje masowe - czynnik przemian współczesnych społeczeństw, [w:] Migracje i społeczeństwo. Zbiór studiów, red. J.E. Zamojski, Warszawa 1995.

\section{Sondaże opinii}

Internauci 2015, 2015, nr 90, CBOS, Warszawa, czerwiec 2015.

Opinie ludności krajów Europy Środkowej o imigrantach i uchodźcach, BS 2005, nr 60, CBOS, Warszawa, marzec 2005.

Opinie ludności z krajów Europy Środkowej o imigrantach i uchodźcach, BS 2005, nr 60, CBOS, Warszawa, marzec 2005.

Polacy o uchodźcach w Internecie i w „realu”, 2015, nr 149, CBOS, Warszawa, listopad 2015.

Polacy wobec problemu uchodźctwa, 2015, nr 81, CBOS, Warszawa, czerwiec 2015.

Przybysze z bliska i daleka, czyli o imigrantach w Polsce, 2015, nr 93, CBOS, Warszawa, czerwiec 2015.

Stosunek do uchodźców w krajach Grupy Wyszehradzkiej, 2015, nr 151, CBOS, Warszawa, listopad 2015.

Stosunek do imigrantów w krajach Grupy Wyszehradzkiej, 2015, nr 178, CBOS, Warszawa, grudzień 2015.

Stosunek Polaków do przyjmowania uchodźców, 2016, nr 12, CBOS, Warszawa, styczeń 2016.

\section{Źródła internetowe}

Gmiterek-Zabłocka A., Wrześniowy pik w zgłoszeniach mowy nienawiści. „90 proc. dotyczy internetu. Już nie to, że są wulgarne. Łamią Kodeks Karny”, 2.11.2015, http://www.tokfm.pl/Tokfm /1,103454,19127446,wrzesniowy-pik-w-zgloszeniach-mowy-nienawisci-90-proc-dotyczy.html.

Jałoszewski M., Andrzej Seremet: Będzie śledztwo za wpisy o „Auschwitz — idealnym pensjonacie dla uchodźców", 5.09.2015, http://wyborcza.pl/1,75478,18715456, andrzej-seremet-bedzie-sledztwo-za-wpisy-o-auschwitz-idealny.html\#ixzz3zf2d6EZ8.

Sawka N., Studenci z Wrocławia widzą w Arabach terrorystów. Zaskakujące wyniki badań [DANE], 02.02.2016, http://wroclaw.wyborcza.pl/wroclaw/1,35771,19567985,studenci-z-wroclawia-widza-w-arabach-terrorystow-zaskakujace.html\#ixzz3zH1VK2oc.

Po tekście „Wyborczej”. Prokuratura wszczęła dochodzenie ws. rasistowskich wpisów o uchodźcach, 8.09.2015, http://wyborcza.pl/1,75478,18736543,po-tekscie-wyborczej-prokuratura-wszczela-dochodzenie-ws.html\#ixzz3zf3slfMp. 